\title{
Erratum to: Protective Effects of Acetyl-L-Carnitine on Cisplatin Cytotoxicity and Oxidative Stress in Neuroblastoma
}

Zekiye Sultan Altun • Dilek Güneş •

Safiye Aktaş • Zübeyde Erbayraktar •

Nur Olgun

Published online: 27 February 2010

(C) Springer Science+Business Media, LLC 2010

Erratum to: Neurochem Res (2010) 35:437-443

DOI 10.1007/s11064-009-0076-8

Unfortunately, in the original version of this article sur name of author Zübeyde has been miss spelled. Instead of Zübeyde Erbayrktar it should be Zübeyde Erbayraktar.

The online version of the original article can be found under doi:10.1007/s11064-009-0076-8.

Z. S. Altun $(\bowtie) \cdot$ S. Aktaş $\cdot$ Z. Erbayraktar Department of Basic Oncology, Institute of Oncology, Dokuz Eylul University, Inciralt1, 35340 Izmir, Turkey

e-mail: zekiye.altun@deu.edu.tr

D. Güneş · N. Olgun

Department of Pediatric Oncology, Institute of Oncology, Dokuz

Eylul University, Izmir, Turkey 